\title{
Somatostatin receptor subtype 2-mediated uptake of radiolabelled somatostatin analogues in the human kidney
}

\author{
Edgar J. Rolleman • Peter P. M. Kooij • \\ Wouter W. de Herder • Roelf Valkema • \\ Eric P. Krenning • Marion de Jong
}

Received: 21 January 2007 / Accepted: 12 March 2007 / Published online: 2 June 2007

(C) Springer-Verlag 2007

\begin{abstract}
Purpose Renal irradiation is a dose-limiting factor in peptide receptor radionuclide therapy using radiolabelled somatostatin analogues. This irradiation is mainly caused by reabsorption of radiolabelled peptides in the proximal tubule. In the human kidney, somatostatin receptors are expressed in the vasa recta, tubuli and glomeruli. It is not clear to what extent these receptors contribute to the total kidney radioactivity uptake.

Methods Retrospectively, $\left[{ }^{111}\right.$ In-DTPA $\left.{ }^{0}\right]$ octreotide scans of ten selected patients with carcinoids (well-differentiated gastrointestinal endocrine tumour) with liver metastases were evaluated. For each patient, two scans were obtained: one scan was performed without (control) and one during treatment with unlabelled octreotide. Kidney, tumour, spleen and liver uptake was measured in both scans.

Results The interval between the two scans per patient varied from 50 to 397 days. Octreotide treatment substantially lowered kidney $\left[{ }^{111}\right.$ In-DTPA $\left.{ }^{0}\right]$ octreotide uptake in eight out of ten patients. Kidney uptake in all patients was reduced to $82 \% \pm 15 \%$ of control, $(p<0.01)$. A correlation between kidney uptake and spleen uptake was found $(r=0.67, p<0.05)$. Serum creatinine was unchanged. Surprisingly, tumour and liver $\left[{ }^{111}\right.$ In-DTPA $\left.{ }^{0}\right]$ octreotide uptake was not significantly influenced by unlabelled octreotide
\end{abstract}

E. J. Rolleman $(\bowtie) \cdot$ P. P. M. Kooij • R. Valkema

E. P. Krenning $\cdot$ M. de Jong

Department of Nuclear Medicine, Erasmus MC,

Room L244, 's Gravendijkwal 230,

3015 CE Rotterdam, The Netherlands

e-mail: e.rolleman@erasmusmc.nl

W. W. de Herder · E. P. Krenning

Department of Internal Medicine, Erasmus MC,

Rotterdam, The Netherlands therapy, but spleen uptake was significantly lowered by treatment ( $30.6 \%$ of control, $p<0.002)$.

Conclusion We conclude that the somatostatin receptor plays a role in the total renal uptake of radiolabelled somatostatin analogues. The long interval between scans might explain the finding that tumour and liver metastasis uptake of $\left[{ }^{111} \mathrm{In}\right.$ DTPA $^{0}$ ]octreotide was unchanged. Further studies are needed to confirm and eludicate the results of this study.

Keywords PRRT · Kidney · Somatostatin receptor subtype 2. Carcinoid - Octreotide

\section{Introduction}

The finding that neuroendocrine tumours have a high expression of somatostatin receptors has led to new diagnostic and therapeutic strategies for these tumours. In recent years many peptide receptor radionuclide therapy (PRRT) clinical trials have been conducted using radiolabelled somatostatin analogues, with promising results [1-6].

In PRRT, the kidney radiation dose is the major doselimiting factor, being caused by uptake of a few percent of the injected dose after glomerular filtration and the subsequent long residence of radioactivity in the kidney cells. Based on external beam radiation data, kidney radiation doses of 23-27 Gy are generally accepted as safe [7]. Follow-up studies after PRRT have suggested that the maximum safe kidney dose, calculated as the biological equivalent dose using the linear quadratic model, might be about 37 Gy [8,9]. When renal uptake of radiolabelled somatostatin analogues can be significantly lowered, larger total radioactivity doses can be injected within the boundaries of these maximum renal radiation doses, thereby enlarging the therapeutic window for PRRT. 
It was recently shown that renal uptake of somatostatin analogues can be inhibited by maleic acid, which interferes with cellular energy supplies [10], by colchicine [11] due to dysfunction of proximal tubule reabsorption processes and by positively charged amino acids such as lysine and arginine $[10,12,13]$. Based on animal studies and clinical data [6, 14-17], PRRT is nowadays performed by coinfusion of lysine and arginine for kidney protection. All these data point to the proximal tubule as the main site of kidney uptake, but the specific mechanism of renal uptake has not yet been fully elucidated. From in vitro studies with opossum kidney cells it was suggested that megalin, a multiligand endocytic protein, is involved in the uptake process [18], which is strongly supported by our recent findings of low renal uptake of $\left[{ }^{111}\right.$ In-DTPA $\left.{ }^{0}\right]$ octreotide in kidney-specific megalin-deficient mice [19]. For more specific renal prevention strategies it is important to know the mechanism and site of renal uptake of somatostatin analogues.

Using binding and immunohistochemistry studies, Reubi et al. [20] found that the vasa recta in human kidney express somatostatin type $2\left(\mathrm{sst}_{2}\right)$ receptors in a high density. $\mathrm{Sst}_{2}$ receptors were also demonstrated in tubular cells of the renal cortex, but at a lesser density. Balster et al. [21] showed mRNA of the somatostatin receptor subtypes 1 and 2 in nine out of nine human kidneys. With antisera they found that $\mathrm{sst}_{2}$, but not $\mathrm{sst}_{1}$, was expressed on the glomeruli, whereas both subtypes could be demonstrated on distal tubule cells and on the thick ascending limb of Henle's loop.

The aim of the present study was to establish the contribution of renal $\mathrm{sst}_{2}$ receptors to the total kidney uptake of radiolabelled somatostatin analogues. Because a rat model is not suitable - the rat kidney does not express somatostatin receptors-we retrospectively examined $\left[{ }^{111}\right.$ In-DTPA $\left.{ }^{0}\right]$ octreotide scans of carcinoid patients with and without high-dose octreotide therapy.

\section{Materials and methods}

\section{Patients}

From our database, ten patients with a carcinoid tumour (well-differentiated gastrointestinal endocrine tumour) were selected who had been investigated with two diagnostic $\left[{ }^{111}\right.$ In-DTPA $\left.{ }^{0}\right]$ octreotide scans. One scan was performed without treatment and one during treatment with high-dose octreotide for relief of carcinoid syndrome symptoms. The interval between scans was 50-397 days (mean 275 days, SD 102 days). No other medical anti-tumour therapy or surgery was given in between scans. Octreotide was either administered as the short-acting Sandostatine (Novartis, Brussels, Belgium) or the long-acting Sandostatine LAR. Doses varied between 200 and $300 \mu \mathrm{g}$ per day and between 20 and $30 \mathrm{mg}$ per 28 days, respectively. Patients initially were treated with octreotide as the gold standard in our hospital, but after the long-acting Sandostatine LAR became available, this became the treatment modality of choice. Doses were adjusted individually on the basis of symptoms. For the patients treated with the LAR-octreotide, the interval between the last octreotide-LAR injection and the scan was 4-21 days. Table 1 summarises the patients' characteristics.

\section{Radiolabelling}

Commercially available kits of $\left[\mathrm{DTPA}^{0}\right]$ octreotide and ${ }^{111} \mathrm{InCl}_{3}$ were obtained from Mallinckrodt (Petten, The Netherlands). The radiolabelling procedure was performed in accordance with standard procedures [22, 23].

Measurement of kidney uptake of $\left[{ }^{111}\right.$ In-DTPA $\left.{ }^{0}\right]$ octreotide

Uptake of $\left[{ }^{111}\right.$ In-DTPA $\left.{ }^{0}\right]$ octreotide in left kidney, spleen, liver and tumour was calculated as percentage uptake of the

Table 1 Patient characteristics

\begin{tabular}{lllll}
\hline Patient & & Localisation & Octreotide & Octreotide dose \\
\hline PB & $75 / \mathrm{F}$ & Small intestine + appendix & LAR-octreotide & $30 \mathrm{mg}$ every 4 weeks \\
JD & $75 / \mathrm{F}$ & Unknown origin & LAR-octreotide & $20 \mathrm{mg}$ every 4 weeks \\
AJ & $52 / \mathrm{M}$ & Small intestine & LAR-octreotide & $30 \mathrm{mg}$ every 4 weeks \\
HM & $64 / \mathrm{F}$ & Small intestine & LAR-octreotide & $20 \mathrm{mg}$ every 4 weeks \\
MS & $75 / \mathrm{M}$ & Small intestine & LAR-octreotide & 20 mg every 4 weeks \\
JJ & $65 / \mathrm{F}$ & Small intestine & Octreotide & 3 injections of $100 \mu \mathrm{g}$ each day \\
AS & $62 / \mathrm{F}$ & Unknown origin & Octreotide & 3 injections of $100 \mu \mathrm{gg}$ each day \\
RW & $60 / \mathrm{M}$ & Small intestine & Octreotide & 2 injections of $100 \mu \mathrm{g}$ each day \\
JB & $47 / \mathrm{M}$ & Appendix & Octreotide & 3 injections of $100 \mu \mathrm{g}$ each day \\
PP & $38 / \mathrm{F}$ & Unknown origin & Octreotide & 3 injections of $100 \mu \mathrm{g}$ each day \\
\hline
\end{tabular}

LAR-octreotide the long-acting Sandostatine LAR 
Table 2 Left kidney uptake of $\left[{ }^{111}\right.$ In-DTPA $\left.{ }^{0}\right]$ octreotide during octreotide treatment, expressed as $\%$ of the scan performed without octreotide treatment ( $\%$ of control)

\begin{tabular}{lll}
\hline Patient & Age (yrs)/sex & $\begin{array}{l}\text { Kidney uptake during octreotide } \\
\text { treatment } \% \text { of control) }\end{array}$ \\
\hline PB & $75 / \mathrm{F}$ & 83 \\
JD & $75 / \mathrm{F}$ & 91 \\
AJ & $52 / \mathrm{M}$ & 74 \\
$\mathrm{HM}$ & $64 / \mathrm{F}$ & 68 \\
$\mathrm{MS}$ & $75 / \mathrm{M}$ & 109 \\
$\mathrm{JJ}$ & $65 / \mathrm{F}$ & 74 \\
AS & $62 / \mathrm{F}$ & 101 \\
RW & $60 / \mathrm{M}$ & 80 \\
JB & $47 / \mathrm{M}$ & 87 \\
PP & $38 / \mathrm{F}$ & 58 \\
Mean \pm SD & & $82 \pm 15^{*}$ \\
\hline
\end{tabular}

${ }^{*} p<0.01$

injected dose using conjugate-view abdominal planar scintigraphy at $24 \mathrm{~h}$ post injection of $220 \mathrm{MBq}\left[{ }^{111} \mathrm{In}\right.$ DTPA $^{0}$ ]octreotide. Planar scintigraphy was performed with a dual-head gamma camera (2000XP, Philips Medical Systems, Eindhoven, The Netherlands) fitted with a medium-energy collimator. The energy windows were set at $\pm 15 \%$ and acquisition times were 15 min.

\section{Statistics}

Wilcoxon paired non-parametric test was used for intrapatient comparisons. $p$-values $<0.05$ were considered statistically significant.

\section{Results}

Left kidneys were clearly visible on all scintigrams, but overprojection of the liver made measurement of the right kidney unreliable.

Table 1 shows the characteristics of the ten included patients, who all had liver metastases.

Left kidney radioactivity at $24 \mathrm{~h}$ p.i. ranged from $0.2 \%$ to $1.05 \%$ of the injected dose; during octreotide treatment, left kidney radioactivity ranged from $0.2 \%$ to $1.07 \%$ of injected dose. Table 2 shows the left kidney uptake of $\left[{ }^{111}\right.$ In-DTPA $\left.{ }^{0}\right]$ octreotide during octreotide treatment, expressed as percentage of the scan performed without octreotide treatment. In eight out of ten patients, substantial reductions in renal radioactivity were found, ranging from $58 \%$ to $91 \%$ of the scan without octreotide treatment, but in two of the ten patients no reduction in kidney radioactivity uptake was found. The kidney uptake in all patients was reduced by $18 \%$, to $82 \% \pm 15 \%$ of the scan without octreotide treatment $(p<0.01)$.

Figure 1 shows the weak but significant correlation that was found between kidney and spleen uptake $(r=0.67 ; p<$ $0.05)$. There was no correlation between reduction in renal uptake of $\left[{ }^{111}\right.$ In-DTPA $\left.{ }^{0}\right]$ octreotide and the length of the interval between scans (not shown). In addition, no correlation was found between reduction in renal uptake of $\left[{ }^{111}\right.$ In-DTPA $\left.{ }^{0}\right]$ octreotide and the dose of octreotide administered (not shown).

Figure 2 shows the serum creatinine values at the time of the standard scan and at the time of the scan during octreotide treatment. During octreotide treatment, the serum creatinine was not significantly different from that during the control situation.

Table 3 shows the uptake of $\left[{ }^{111}\right.$ In-DTPA $\left.{ }^{0}\right]$ octreotide in the left kidney, liver, spleen and tumour in patients receiving octreotide therapy, expressed as percentage of the uptake measured without this treatment. Spleen uptake was significantly reduced by octreotide treatment, but tumour and liver uptake was not.

Table 4 summarises the individual values for tumour uptake (expressed as percentage of control) in each patient. Table 4 also shows the changes in disease during the interval between scans, as measured by computer tomography (CT) or magnetic resonance imaging (MRI). No clear correlation could be found between increases in tumour uptake and changes in disease activity, e.g. progression.

The patients who were treated with LAR-octreotide had tumour uptake values of $97 \pm 35 \%$ of control, not significantly different from control. The patients who were treated with octreotide had tumour uptake values of $74 \pm 32 \%$ of control, again not significantly different from control.

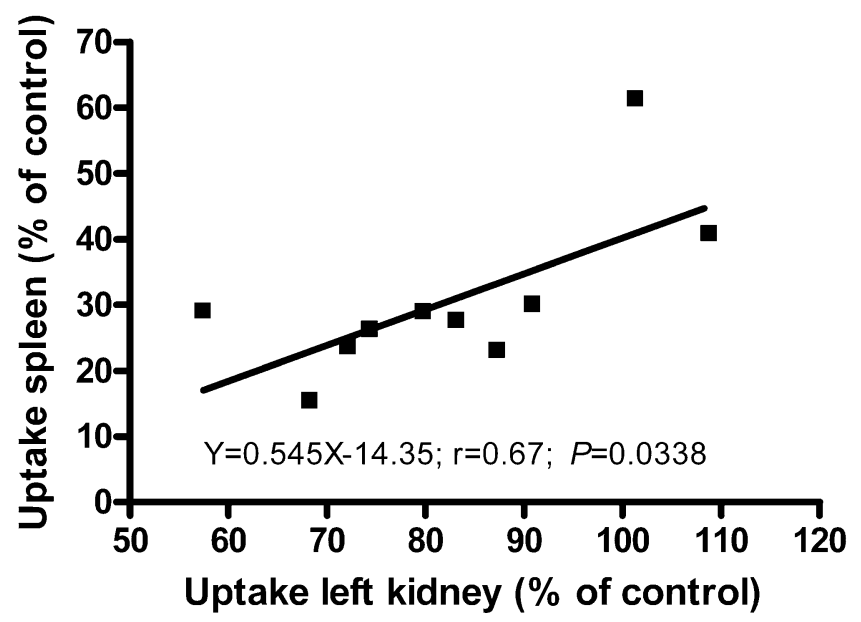

Fig. 1 Correlation of effects of octreotide treatment on kidney uptake and on spleen uptake $24 \mathrm{~h}$ after injection of $220 \mathrm{MBq}\left[{ }^{111} \mathrm{In}_{-\mathrm{DTPA}}{ }^{0}\right.$ ] octreotide. Data are expressed as percentage of the scan without octreotide treatment 


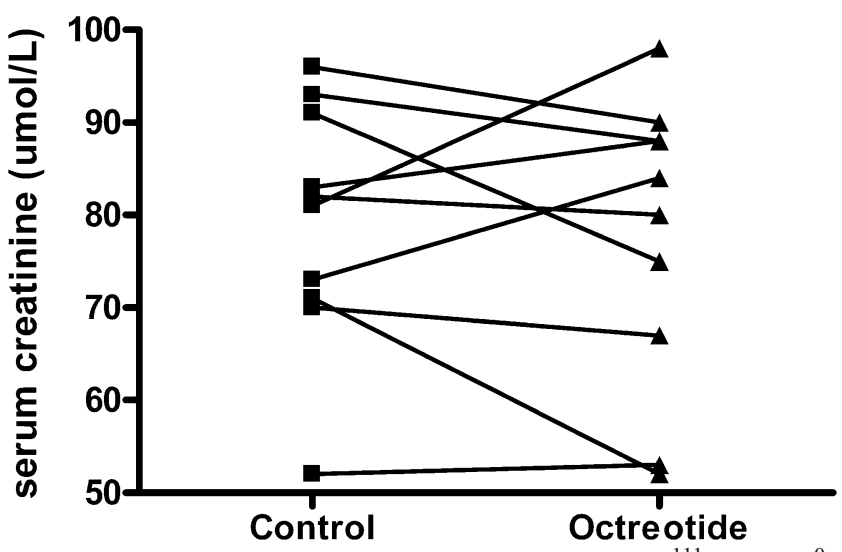

Fig. 2 Serum creatinine values at the times of $\left[{ }^{111}{ }^{1 n}-D_{T P A}{ }^{0}\right]$ octreotide scintigrams before and during octreotide treatment

\section{Discussion}

During PRRT, the kidney radiation dose is the major factor that limits the total administered dose and the radiation dose to the tumour. Renal uptake of radiolabelled somatostatin analogues and subsequent long retention of radioactivity are responsible for this kidney radiation.

In order to interfere with this uptake successfully, it is essential to understand the exact uptake mechanism. The major part of kidney uptake of radiolabelled somatostatin analogues is via proximal tubular reabsorption. This is supported by the finding of several groups that positively charged amino acids, like lysine and arginine, can reduce the kidney uptake of radiolabelled somatostatin analogues by about $40-50 \%[10,15,17]$. These amino acids are known to interfere with the proximal tubular reabsorption of small proteins and peptides [24]. Furthermore, we have shown that the kidney uptake of $\left[{ }^{111} \mathrm{In}-\mathrm{DTPA}^{0}\right]$ octreotide in megalin-deficient mice is significantly reduced as compared with normal mice [19]. Megalin is a multi-scavenger molecule that is essential for proximal tubular reabsorption of many low molecular weight proteins. Despite this, the exact localisation and mechanism have not been fully eludicated. As the renal uptake of somatostatin analogues cannot be completely blocked, other mechanisms may be involved.

Table 3 Spleen, liver and tumour uptake of $\left[{ }^{111}\right.$ In-DTPA $\left.{ }^{0}\right]$ octreotide during treatment with unlabelled octreotide, expressed as percentage of uptake without treatment

Uptake (\% of control)

\begin{tabular}{ll}
\hline Spleen & $31 \% \pm 13 \% *$ \\
Liver & $83 \% \pm 32 \% * *$ \\
Tumour & $85 \% \pm 37 \% * *$
\end{tabular}

${ }^{*} p<0.002, * * p=\mathrm{NS}$
Table 4 Tumour uptake of $\left[{ }^{111}\right.$ In-DTPA $\left.{ }^{0}\right]$ octreotide during treatment with unlabelled octreotide, expressed as percentage of a scan without treatment in each individual patient

\begin{tabular}{lll}
\hline Patient & Tumour (\% control) & Disease $^{\mathrm{a}}$ \\
\hline PB & 119 & Stable (MRI) \\
JD & 145 & Progression (MRI) \\
AJ & 70 & Stable (MRI) \\
HM & 46 & Stable (CT) \\
MS & 104 & Stable (CT) \\
JJ & 70 & Stable (CT) \\
AS & 93 & Stable (CT) \\
RW & 117 & Regression (CT) \\
JB & 67 & Stable (CT) \\
PP & 22 & Stable (MRI) \\
\hline
\end{tabular}

${ }^{\text {a }}$ Course of the disease during the interval between scans

${ }^{\mathrm{b}}$ Stable disease on CT, but new lesions on SMS scan

${ }^{\mathrm{c}}$ On $\mathrm{CT}$ the metastasis volumes were unchanged, but there was less necrotic tissue in metastases

${ }^{d}$ Minimal reduction of metastasis size

In the past, $\mathbf{s s t}_{2}$ have been demonstrated in cells of glomeruli [21], tubuli and vasa recta [20]. The present study was performed to elucidate the role of these receptors in renal uptake during scintigraphy and PRRT using somatostatin analogues. We showed that renal uptake of somatostatin analogues is significantly reduced by concomitant treatment with unlabelled octreotide for relief of carcinoid syndrome symptoms. This indicates that binding to the renal $\mathrm{sst}_{2}$ plays a role in the total uptake of radiolabelled somatostatin analogues in the kidneys and thus in the resulting renal radiation dose. We could not find a clear dose relationship in these ten patients, but the correlation observed between spleen uptake and kidney uptake suggests a dose dependency.

One could argue that the effects of octreotide treatment on kidney uptake of $\left[{ }^{111} \mathrm{In}\right.$-DTPA $\left.{ }^{0}\right]$ octreotide might not be caused by ousting of the radioligand from the $\mathrm{sst}_{2}$ by the cold octreotide, but by other factors, such as haemodynamic changes due to high octreotide levels. There is some controversy in the literature on the effects of somatostatin and somatostatin analogues on kidney function parameters. Table 5 summarises all human data on the effects of somatostatin or octreotide on kidney function. Somatostatin and octreotide have been described in healthy subjects and patients with diabetes mellitus and acromegaly to decrease renal plasma flow (RPF) and concomitantly decrease glomerular filtration rate (GFR) with an unchanged filtration fraction [25-32]. However, it should be noted that some of these studies administered supraphysiological doses of somatostatin $[100-420 \mu \mathrm{g} / \mathrm{h}$ intravenously (IV) or $600 \mu \mathrm{g} /$ day subcutaneously (SC)]. In contrast, the study by Castellino et al. [33] applied $480 \mu \mathrm{g} / \mathrm{h}$ somatostatin in 18 healthy subjects and did not find any effect on the GFR. Studies that applied octreotide doses comparable to the 
doses in our patient group showed conflicting results as well. Tulassay et al. [34] administered $100 \mu \mathrm{g}$ octreotide subcutaneously and found a significant decrease in GFR of $47 \%$, which lasted up to $8 \mathrm{~h}$. Studies performed in cirrhotic patients, growth hormone-deficient patients and patients with mild to moderate renal insufficiency did not find significant changes in either RPF or GFR [33, 35-42]. It must be stressed that the studies listed in Table 5 describe the relatively short-term (hours to months) effects of somatostatin or its analogues on kidney function. Patients suffering from neuroendocrine tumours are usually treated for years with unlabelled somatostatin analogues. In our study, serum creatinine values did not change during treatment with octreotide, suggesting that there were no major changes in GFR in our patients that could have biased our findings.

In the present study, the variable effects of octreotide treatment on tumour and liver uptake were unexpected. As these tumours and metastases are somatostatin receptorpositive, one would expect an unequivocal reduction in $\left[{ }^{111}\right.$ In-DTPA $\left.{ }^{0}\right]$ octreotide uptake in them. A possible expla- nation for our findings could be progression of the tumour at the time of the scan during octreotide treatment. As shown in Table 4, in only one patient with an increase in tumour $\left[{ }^{111}\right.$ In-DTPA $\left.{ }^{0}\right]$ octreotide uptake during octreotide treatment was disease progression present. Two patients with progressive disease, however, had a strong reduction in tumour and liver uptake. Patients with stable disease could had either a strong reduction or an increase in $\left[{ }^{111} \mathrm{In}\right.$ $\left.\mathrm{DTPA}^{0}\right]$ octreotide uptake during octreotide treatment.

Interestingly, patients treated with the long-acting LARoctreotide seemed to have a smaller reduction $(3 \% \pm 35 \%)$ in tumour uptake of $\left[{ }^{111} \mathrm{In}-\mathrm{DTPA}{ }^{0}\right]$ octreotide than those treated with octreotide $(26 \% \pm 32 \%)$, although this difference was not statistically significant and large variations were present in both groups. This, taken together with the reduced kidney uptake caused by both octreotide and LAR-octreotide, might provide a basis in the future for continuation of LAR-octreotide treatment during PRRT as it causes little reduction in tumour uptake but sustained kidney uptake reduction, enlarging the therapeutic window of PRRT. Larger studies that apply smaller intervals

Table 5 Summary of human studies on renal effects of somatostatin or octreotide

\begin{tabular}{|c|c|c|c|}
\hline Authors & Subjects & Dosage & Major finding \\
\hline Serri et al. [25] & Diabetics $(n=11)$ & $\begin{array}{l}\text { Cont. SC infusion of } 300 \mu \mathrm{g} \\
\text { octreotide/day for } 12 \text { weeks }\end{array}$ & $\begin{array}{l}\text { GFR } 136 \mathrm{ml} / \mathrm{min} \text { vs } 157 \mathrm{ml} / \mathrm{min} \text { in } \\
\text { placebo group }\end{array}$ \\
\hline Luksch et al. [26] & Healthy $(n=3)$ & $6 \mu \mathrm{g} / \mathrm{kg} / \mathrm{h}$ somatostatin IV, for $3 \mathrm{~h}$ & Inulin clearance $131 \rightarrow 124 \mathrm{ml} / \mathrm{min}$ \\
\hline Schmidt et al. [27] & Healthy $(n=9)$ & $6 \mu \mathrm{g} / \mathrm{kg} / \mathrm{h}$ somatostatin IV, for $3 \mathrm{~h}$ & Inulin clearance $138 \rightarrow 119 \mathrm{ml} / \mathrm{min}$ \\
\hline Tulassay et al. [28] & Healthy $(n=7)$ & $250 \mu \mathrm{g}$ somatostatin $/ \mathrm{h} \mathrm{IV}$, for $2 \mathrm{~h}$ & Inulin clearance $131 \rightarrow 62 \mathrm{ml} / \mathrm{min}$ \\
\hline Vora et al. [29] & $\begin{array}{l}\text { Healthy }(n=6) \text { and } \\
\text { diabetics }(n=9)\end{array}$ & $100 \mu \mathrm{g}$ somatostatin $/ \mathrm{h} \mathrm{IV}$, for $2 \mathrm{~h}$ & ${ }^{51} \mathrm{Cr}$-EDTA clearance $112 \rightarrow 95 \mathrm{ml} / \mathrm{min}$ \\
\hline Dullaart et al. [30] & Acromegaly $(n=7)$ & T.i.d. $100 \mu \mathrm{g}$ octreotide, for 3 months & $\begin{array}{l}{ }^{125} \text { I-iothalamate clearance } 132 \rightarrow 117 \\
\mathrm{ml} / \mathrm{min}\end{array}$ \\
\hline Kalambokis et al. [31] & Cirrhotics $(n=25)$ & $\begin{array}{l}\text { B.i.d. } 300 \mu \mathrm{g} \text { octreotide } \mathrm{SC} \text {, for } \\
11 \text { days }\end{array}$ & $\begin{array}{l}\text { Higher RPF flow but }{ }^{99 \mathrm{~m}} \mathrm{Tc}-\mathrm{DTPA} \\
\text { clearance } 95 \rightarrow 79 \mathrm{ml} / \mathrm{min}\end{array}$ \\
\hline Kalambokis et al. [32] & Cirrhotics $(n=20)$ & $\begin{array}{l}\text { B.i.d. } 300 \mu \mathrm{g} \text { octreotide } \mathrm{SC} \text {, for } \\
14 \text { days }\end{array}$ & ${ }^{99 \mathrm{~m}}$ Tc-DTPA clearance $79 \rightarrow 72 \mathrm{ml} / \mathrm{min}$ \\
\hline Castellino et al. [33] & Healthy $(n=18)$ & $480 \mu \mathrm{g} / \mathrm{h}$ somatostatin IV, for $3 \mathrm{~h}$ & $\begin{array}{l}\text { No effect of somatostatin on inulin } \\
\text { clearance }\end{array}$ \\
\hline Tulassay et al. [34] & Healthy $(n=8)$ & $100 \mu \mathrm{g}$ octreotide $\mathrm{SC}$, once & Creatinine clearance $124 \rightarrow 66 \mathrm{ml} / \mathrm{min}$ \\
\hline Krempf et al. [35] & Diabetics $(n=5)$ & $480 \mu \mathrm{g}$ octreotide IV/h, for $10 \mathrm{~h}$ & ${ }^{99 \mathrm{~m}}$ Tc-DTPA clearance unchanged \\
\hline Malesci et al. [36] & Cirrhotics $(n=11)$ & $\begin{array}{l}\text { T.i.d. } 100 \mu \mathrm{g} \text { octreotide SC, for } 2 \\
\text { weeks }\end{array}$ & Inulin clearance $99 \rightarrow 99 \mathrm{ml} / \mathrm{min}$ \\
\hline Ruggenenti et al. [37] & Cystic kidneys $(n=14)$ & $\begin{array}{l}40 \text { mg LAR-octreotide SC every } \\
4 \text { weeks, for } 6 \text { months }\end{array}$ & Unchanged iohexol plasma clearance \\
\hline Sabat et al. [38] & Cirrhotics $(n=20)$ & $\begin{array}{l}\text { B.i.d. } 250 \mu \mathrm{g} \text { octreotide SC, for } \\
5 \text { days }\end{array}$ & Creatinine clearance $61 \rightarrow 65 \mathrm{ml} / \mathrm{min}$ \\
\hline Dullaart et al. [39] & GH-deficient $(n=7)$ & $\begin{array}{l}10 \mu \mathrm{g} / \mathrm{h} \text { IV plus } 4 \text { injections } 100 \mu \mathrm{g} \\
\text { octreotide SC }\end{array}$ & ${ }^{125}$ I-iothalamate clearance unchanged \\
\hline Mountokalakis et al. [40] & Cirrhotics $(n=9)$ & $40 \mu \mathrm{g} / \mathrm{h}$ octreotide IV, for $2 \mathrm{~h}$ & Creatinine clearance higher \\
\hline Ottesen et al. [41] & Cirrhotics $(n=25)$ & $\begin{array}{l}20 \text { mg LAR-octreotide SC every } \\
4 \text { weeks }\end{array}$ & $\begin{array}{l}{ }^{51} \text { Cr-EDTA clearance } 120 \rightarrow 114 \mathrm{ml} / \mathrm{min} \\
\text { (NS) }\end{array}$ \\
\hline Pomier-Layrargues et al. [42] & $\begin{array}{l}\text { Hepatorenal syndrome } \\
(n=14)\end{array}$ & $50 \mu \mathrm{g} / \mathrm{h} \mathrm{IV}$, for 2 days & Creatinine clearance unchanged \\
\hline
\end{tabular}


between the scans are needed before such a strategy can be implemented in PRRT protocols, however. In our study, the interval between the scan without and that with octreotide treatment was long, and it is hard to tell exactly what happens in the tumours at the level of receptor numbers and receptor density.

Dorr et al. [43] previously showed diminished kidney, liver and spleen uptake during octreotide treatment with $600 \mu \mathrm{g}$ per day, yet improved tumour visualisation by somatostatin analogue treatment. Our results are not in line with their findings: indeed we found significant reduction in kidney uptake, but in four of five patients treated with three daily injections of octreotide we also found a considerable reduction in tumour uptake, applying even a lower dose (200 or $300 \mu \mathrm{g} /$ day) than Dorr et al. Owing to the small number of patients and the large inter-individual variation, the mean tumour uptake was not significantly reduced by unlabelled octreotide treatment.

\section{Conclusion}

We showed that during treatment with octreotide for symptom relief, kidney uptake of $\left[{ }^{111}\right.$ In-DTPA $\left.{ }^{0}\right]$ octreotide was decreased by about $18 \%$ in ten patients with carcinoid tumours. This indicates a substantial contribution of renal sst $_{2}$ to the total kidney uptake of radiolabelled somatostatin analogues. The effects of octreotide and LAR-octreotide on tumour and liver metastases were not expected: we did not find a significant reduction of tumour uptake. The large interval between scans might be a confounding factor, as might the small number of patients evaluated.

\section{References}

1. Valkema R, De Jong M, Bakker WH, Breeman WA, Kooij PP, Lugtenburg PJ, et al. Phase I study of peptide receptor radionuclide therapy with $\left[{ }^{111} \mathrm{In}-\mathrm{DPTA}{ }^{0}\right]$ octreotide: the Rotterdam experience. Semin Nucl Med 2002;32:110-22.

2. Otte A, Herrmann R, Heppeler A, Behe M, Jermann E, Powell P, et al. Yttrium-90 DOTATOC: first clinical results. Eur J Nucl Med 1999;26:1439-47.

3. Kwekkeboom DJ, Bakker WH, Kam BL, Teunissen JJ, Kooij PP, de Herder WW, et al. Treatment of patients with gastro-enteropancreatic (GEP) tumours with the novel radiolabelled somatostatin analogue $\left[{ }^{177} \mathrm{Lu}-\mathrm{DOTA}{ }^{0}, \mathrm{Tyr}^{3}\right]$ octreotate. Eur J Nucl Med Mol Imaging 2003;30:417-22.

4. Kwekkeboom DJ, Mueller-Brand J, Paganelli G, Anthony LB, Pauwels S, Kvols LK, et al. Overview of results of peptide receptor radionuclide therapy with 3 radiolabeled somatostatin analogs. J Nucl Med 2005;46:62S-6S.

5. Virgolini I, Britton K, Buscombe J, Moncayo R, Paganelli G, Riva P. In- and Y-DOTA-lanreotide: results and implications of the MAURITIUS trial. Semin Nucl Med 2002;32:148-55.

6. Bodei L, Cremonesi M, Grana C, Rocca P, Bartolomei M, Chinol $\mathrm{M}$, et al. Receptor radionuclide therapy with ${ }^{90} \mathrm{Y}-[\mathrm{DOTA}]^{0}-\mathrm{Tyr}^{3}-$ octreotide $\left({ }^{90}\right.$ Y-DOTATOC) in neuroendocrine tumours. Eur J Nucl Med Mol Imaging 2004;31:1038-46.

7. Emami B, Lyman J, Brown A, Coia L, Goitein M, Munzenrider $\mathrm{JE}$, et al. Tolerance of normal tissue to therapeutic irradiation. Int J Radiat Oncol Biol Phys 1991;21:109-22.

8. Valkema R, Pauwels SA, Kvols LK, Kwekkeboom DJ, Jamar F, de Jong $M$, et al. Long-term follow-up of renal function after peptide receptor radiation therapy with ${ }^{90} \mathrm{Y}^{-D_{0}} \mathrm{TA}^{0}, \mathrm{Tyr}^{3}$-Octreotide and ${ }^{177} \mathrm{Lu}^{-D O T A}{ }^{0}$, $\mathrm{Tyr}^{3}$-Octreotate. J Nucl Med 2005; 46:83S-91S.

9. Barone R, Borson-Chazot F, Valkema R, Walrand S, Chauvin F, Gogou L, et al. Patient-specific dosimetry in predicting renal toxicity with ${ }^{90}$ Y-DOTATOC: Relevance of kidney volume and dose rate in finding a dose-effect relationship. J Nucl Med 2005;46:99S-106S.

10. De Jong M, Rolleman EJ, Bernard BF, Visser TJ, Bakker WH, Breeman WA, et al. Inhibition of renal uptake of indium-111DTPA-octreotide in vivo. J Nucl Med 1996;37:1388-92.

11. Rolleman EJ, Krenning EP, Van Gameren A, Bernard BF, De Jong M. Uptake of $\left[{ }^{111}\right.$ In-DTPA $\left.{ }^{0}\right]$ octreotide in the rat kidney is inhibited by colchicine and not by fructose. J Nucl Med 2004;45:709-13.

12. Hammond PJ, Wade AF, Gwilliam ME, Peters AM, Myers MJ, Gilbey SG, et al. Amino acid infusion blocks renal tubular uptake of an indium-labelled somatostatin analogue. $\mathrm{Br} \mathrm{J}$ Cancer 1993;67:1437-9.

13. Behr TM, Sharkey RM, Juweid ME, Blumenthal RD, Dunn RM, Griffiths GL, et al. Reduction of the renal uptake of radiolabeled monoclonal antibody fragments by cationic amino acids and their derivatives. Cancer Res 1995;55:3825-34.

14. Bernard BF, Krenning EP, Breeman WA, Rolleman EJ, Bakker WH, Visser TJ, et al. D-Lysine reduction of indium-111 octreotide and yttrium-90 octreotide renal uptake. J Nucl Med 1997;38:1929-33.

15. Rolleman EJ, Valkema R, De Jong M, Kooij PP, Krenning EP. Safe and effective inhibition of renal uptake of radiolabelled octreotide by a combination of lysine and arginine. Eur $\mathrm{J}$ Nucl Med Mol Imaging 2003;30:9-15.

16. Barone R, Pauwels S, De Camps J, Krenning EP, Kvols LK, Smith MC, et al. Metabolic effects of amino acid solutions infused for renal protection during therapy with radiolabelled somatostatin analogues. Nephrol Dial Transplant 2004;19:2275-81.

17. Jamar F, Barone R, Mathieu I, Walrand S, Labar D, Carlier P, et al. ${ }^{86}$ Y-DOTA $^{0}$-D-Phe ${ }^{1}-$ Tyr $^{3}$-octreotide (SMT487) - a phase 1 clinical study: pharmacokinetics, biodistribution and renal protective effect of different regimens of amino acid co-infusion. Eur J Nucl Med Mol Imaging 2003;30:510-8.

18. Barone R, Van Der Smissen P, Devuyst O, Beaujean V, Pauwels S, Courtoy PJ, et al. Endocytosis of the somatostatin analogue, octreotide, by the proximal tubule-derived opossum kidney (OK) cell line. Kidney Int 2005;67:969-76.

19. De Jong M, Barone R, Krenning E, Bernard B, Melis M, Visser T, et al. Megalin is essential for renal proximal tubule reabsorption of ${ }^{111}$ In-DTPA-octreotide. J Nucl Med 2005;46:1696-700.

20. Reubi JC, Horisberger U, Studer UE, Waser B, Laissue JA. Human kidney as target for somatostatin: high affinity receptors in tubules and vasa recta. J Clin Endocrinol Metab 1993;77:1323-8.

21. Balster DA, O’Dorisio MS, Summers MA, Turman MA. Segmental expression of somatostatin receptor subtypes sst(1) and sst(2) in tubules and glomeruli of human kidney. Am J Physiol Renal Physiol 2001;280:F457-65.

22. Krenning EP, Kwekkeboom DJ, Bakker WH, Breeman WA, Kooij PP, Oei HY, et al. Somatostatin receptor scintigraphy with $\left[{ }^{111}\right.$ In-DTPA-D$\left.\mathrm{Phe}^{1}\right]$ - and $\left[{ }^{123}{ }^{\mathrm{I}}-\mathrm{Tyr}^{3}\right]$-octreotide: the Rotterdam experience with more than 1000 patients. Eur J Nucl Med 1993;20:716-31. 
23. Bakker WH, Krenning EP, Reubi JC, Breeman WA, Setyono-Han $\mathrm{B}$, de Jong $\mathrm{M}$, et al. In vivo application of [ $\left.{ }^{111} \mathrm{In}-\mathrm{DTPA}-\mathrm{D}-\mathrm{Ph} \mathrm{e}^{1}\right]$ octreotide for detection of somatostatin receptor-positive tumors in rats. Life Sci 1991;49:1593-601.

24. Mogensen CE, Solling. Studies on renal tubular protein reabsorption: partial and near complete inhibition by certain amino acids. Scand J Clin Lab Invest 1977;37:477-86.

25. Serri O, Beauregard H, Brazeau P, Abribat T, Lambert J, Harris A, et al. Somatostatin analogue, octreotide, reduces increased glomerular filtration rate and kidney size in insulin-dependent diabetes. JAMA 1991;265:888-92.

26. Luksch A, Polak K, Matulla B, Dallinger S, Kapiotis S, Rainer G, et al. Glucose and insulin exert additive ocular and renal vasodilator effects on healthy humans. Diabetologia 2001;44:95-103.

27. Schmidt A, Pleiner J, Schaller G, Roden M, Dallinger S, Mayer G, et al. Renal hemodynamic effects of somatostatin are not related to inhibition of endogenous insulin release. Kidney Int 2002;61:1788-93.

28. Tulassay T, Tulassay Z, Rascher W, Szucs L, Seyberth HW, Nagy I. Effect of somatostatin on kidney function and vasoactive hormone systems in health subjects. Klin Wochenschr 1991;69:486-90.

29. Vora J, Owens DR, Luzio S, Atiea J, Ryder R, Hayes TM. Renal response to intravenous somatostatin in insulin-dependent diabetic patients and normal subjects. J Clin Endocrinol Metab 1987;64:975-9.

30. Dullaart RP, Meijer S, Marbach P, Sluiter WJ. Effect of a somatostatin analogue, octreotide, on renal haemodynamics and albuminuria in acromegalic patients. Eur $\mathrm{J}$ Clin Invest 1992;22:494-502.

31. Kalambokis G, Economou M, Fotopoulos A, Al Bokharhii J, Pappas $\mathrm{C}$, Katsaraki A, et al. The effects of chronic treatment with octreotide versus octreotide plus midodrine on systemic hemodynamics and renal hemodynamics and function in nonazotemic cirrhotic patients with ascites. Am J Gastroenterol 2005;100:879-85.

32. Kalambokis G, Economou M, Fotopoulos A, Bokharhii JA, Katsaraki A, Tsianos EV. Renal effects of treatment with diuretics, octreotide or both, in non-azotemic cirrhotic patients with ascites. Nephrol Dial Transplant 2005;20:1623-9.

33. Castellino P, Giordano C, Perna A, DeFronzo RA. Effects of plasma amino acid and hormone levels on renal hemodynamics in humans. Am J Physiol 1988;255:F444-9.
34. Tulassay Z, Tulassay T, Szucs L, Nagy I. Effects of long acting somatostatin analogue on renal functions. Horm Metab Res 1990;22:555-6.

35. Krempf M, Ranganathan S, Remy JP, Charbonnel B, Guillon J. Effect of long-acting somatostatin analog (SMS 201-995) on high glomerular filtration rate in insulin dependent diabetic patients. Int J Clin Pharmacol Ther Toxicol 1990;28:309-11.

36. Malesci A, Tacconi M, Valentini A, Basilico M, Lorenzano E, Salerno F. Octreotide long-term treatment in patients with portal hypertension: persistent inhibition of postprandial glucagon response without major changes in renal function. J Hepatol 1997;26:816-25.

37. Ruggenenti P, Remuzzi A, Ondei P, Fasolini G, Antiga L, Ene-Iordache B, et al. Safety and efficacy of long-acting somatostatin treatment in autosomal-dominant polycystic kidney disease. Kidney Int 2005;68:206-16.

38. Sabat M, Guarner C, Soriano G, Bulbena O, Novella MT, Ortiz J, et al. Effect of subcutaneous administration of octreotide on endogenous vasoactive systems and renal function in cirrhotic patients with ascites. Dig Dis Sci 1998;43:2184-9.

39. Dullaart RP, Meijer S, Marbach P, Sluiter WJ. Renal reserve filtration capacity in growth hormone deficient subjects. Eur J Clin Invest 1992;22:562-8.

40. Mountokalakis T, Kallivretakis N, Mayopoulou-Symvoulidou D, Karvountzis G, Tolis G. Enhancement of renal function by a longacting somatostatin analogue in patients with decompensated cirrhosis. Nephrol Dial Transplant 1988;3:604-7.

41. Ottesen LH, Aagaard NK, Kiszka-Kanowitz M, Rehling M, Henriksen JH, Pedersen EB, et al. Effects of a long-acting formulation of octreotide on renal function and renal sodium handling in cirrhotic patients with portal hypertension: a randomized, double-blind, controlled trial. Hepatology 2001;34:471-7.

42. Pomier-Layrargues G, Paquin SC, Hassoun Z, Lafortune M, Tran A. Octreotide in hepatorenal syndrome: a randomized, doubleblind, placebo-controlled, crossover study. Hepatology 2003;38:238-43.

43. Dorr U, Rath U, Sautter-Bihl ML, Guzman G, Bach D, Adrian $\mathrm{HJ}$, et al. Improved visualization of carcinoid liver metastases by indium-111 pentetreotide scintigraphy following treatment with cold somatostatin analogue. Eur J Nucl Med $1993 ; 20: 431-3$. 